\title{
What International Bureaucrats (Really) Want
}

\section{Administrative Preferences in International Organization Research}

\author{
Jörn Ege \\ German University of Administrative Sciences Speyer, Speyer, Germany \\ and University of Exeter, Exeter, United Kingdom \\ ege@uni-speyer.de
}

\begin{abstract}
The secretariats of international organizations (international public administrations [IPAs]) constitute the institutional grid of global governance. While recent research has provided valuable insights into the independent capacities of international organizations (IOs) and the influence of IPAs, we lack systematic knowledge of how scholars conceptualize the preferences of IO staff. This is lamentable because understanding the (unifying) motivations of "international civil servants" helps us to make sense of their behavior and influence during the adoption and application of IO policies. To review how IPA studies conceptualize the preferences of international bureaucrats, this article suggests a fourfold typology of ideal-typical bureaucratic behavior. It distinguishes between the underlying behavioral logic and dominant bureaucratic goal orientation. Applying the typology to thirty-nine journal articles allows us to map IPA preferences and behavior, and shows that the literature predominantly views IPAs as behaving responsibly and less self-centeredly than could be expected from economic accounts of bureaucracy.
\end{abstract}

\section{Keywords}

literature review - international civil servants - international public administration global public policy - bureaucratic behavior - administrative preferences 
State interests have long been considered the only relevant force driving world politics. However, the dominant perception of international (governmental) organizations (IOs) has shifted. IOs were initially viewed as an instrument for state interests and then as an arena for state interaction before becoming seen as actors in their own right. The independence of IOs from member state interest and their capacity for influence has prompted considerable academic debate. ${ }^{2}$ Building on earlier works, ${ }^{3}$ scholars have started to look into the black box of IO s to understand how intraorganizational decision-making works and why IO s as complex agents act the way they do. ${ }^{4}$ In the context of this debate, the independent preferences and behavior of the people working in IOs have become more and more analytically relevant and scholars have investigated the influence of bureaucrats across various organizations. ${ }^{5}$ But the IO literature remains divided over the questions of what individual international bureaucrats actually want and what drives their behavior as a social group.

Several scholars have described different types of preferences of IO staff, positing that personal gains and organizational gains are the two major reference points for bureaucratic action. For instance, Tana Johnson distinguishes between material interests (personal security) and ideational interests (to advance effective policies). ${ }^{6}$ Others describe international public administration (IPA) preferences in terms of three objectives: advancing cooperation, to the benefit of the IO; policy effectiveness, affirming the technical expertise of IOs; and avoiding uncertainty. ${ }^{7}$ Still others consider that "bureaucracies strive for resources ..., excellence ... and autonomy ..., whereby each of these objectives is considered as goal in its own right and/or as instrumental to achieve the two other objectives." ${ }^{8}$ But these are formative accounts and we lack a more

1 A previous version of this article was presented at the International Conference on Public Policy 2018 in Montreal, Canada. The author thanks the participants of the panel "Bureaucratic Influence in Global Public Policy"-especially the discussant Yves Steinebach. He is also indebted to Michael W. Bauer for his comments on an earlier version of this article, Nick Dickinson for language editing, and Peter Romaniuk for his support in streamlining the final version.

2 Barnett and Finnemore 1999, 2004; Volgy et al. 2008; Haftel and Thompson 2006; Finnemore 1993 .

3 Cox and Jacobson 1973 .

4 Reinalda and Verbeek 2004; Rittberger et al. 2019.

5 Young 1991; Cox 1969; Johnson 2013; Biermann and Siebenhüner 2009.

6 Johnson 2016, 741 .

7 Rittberger et al. 2019 .

8 Michaelowa and Michaelowa 2017, 248; for a similar distinction, see Dreher and Lang 2019. 
systematic understanding of the preferences of international bureaucrats. It is important to develop such an understanding not least because international bureaucrats experience a variety of conflicts of interests-be it between different role understandings ${ }^{9}$ or between their organizational affiliation on the one hand and their nationality on the other. ${ }^{10}$ At the same time, there is consensus that the nature of policy preferences is highly relevant because, while this is beyond the scope of this article, these preferences will eventually affect the activities and decisions of IOs. ${ }^{11}$

To fill this gap, in this article I suggest a typology that distinguishes between the dominant behavioral logic and the underlying bureaucratic goal orientation. Based on this distinction, my typology identified four ideal-typical bureaucratic behaviors and I surveyed IPA research to map how administrative preferences are studied and to synthesize the most important findings of this literature. To do so, I used a systematic approach to select pertinent research and focused on the most recent articles (published between 2015 and 2019) in international relations (IR) and public administration (PA) journals. ${ }^{12}$ This selection procedure resulted in thirty-nine journal articles. Applying the typology to these publications allowed me to map bureaucratic preferences in IPA research and show that the literature predominantly views IPAs as behaving responsibly and less self-centeredly than could be expected from economic accounts of bureaucracy.

This article proceeds as follows: first, I present the common distinction between (neo)institutionalist and constructivist conceptions of international bureaucracy and then relate each conception to one particular behavioral logic as distinguished by James G. March and Johan P. Olsen. ${ }^{13}$ After further introducing two kinds of bureaucratic goal orientation as used in public administration research, I lay out the four ideal types of bureaucratic behavior. Then, I describe the (systematic) literature review and the prevalence of the different types of behavior in IPA research before concluding the article.

\footnotetext{
$9 \quad$ Marcussen and Trondal 2011.

10 Mele, Anderfuhren-Biget, and Varone 2016.

11 Ege, Bauer, and Wagner 2019; see also Dreher and Lang 2019, 618.

12 A list of the articles selected for review and the coding of ideal type behavior can be downloaded from Harvard Dataverse at https://dataverse.harvard.edu/dataset.xhtml?persisten tId=doi:10.7910/DVN/V78JGZ

13 March and Olsen 1984.
} 


\section{Behavior Logics in (Neo)institutionalist and Constructivist Conceptions of International Bureaucracy}

Even though it has been shown that UN agencies are becoming more reluctant to employ staff on permanent contracts, ${ }^{14}$ the average number of people working in IOs has grown over time. At the same time, the authority delegated to IOs has increased substantially. ${ }^{15}$ Hence, the preferences of international bureaucrats are increasingly relevant in understanding global governance and global policy. ${ }^{16}$ Adopting a constructivist approach, Michael Barnett and Martha Finnemore initially highlighted the empirical relevance of bureaucratic preferences in IO research (instead of making assumptions about them based on a generic bureaucratic interest). ${ }^{17}$ While subsequent research agreed on the general analytic relevance of bureaucratic goals and preferences, (neo)institutionalists and constructivists in IR have fiercely debated the nature of these preferences. ${ }^{18}$ As a result, it has been suggested that work in this area should draw on the two well-known behavioral logics distinguished by March and Olsen to generalize about human behavior in social contexts. ${ }^{19}$ A logic of expected consequences, they argue, is one in which "human actors choose among alternatives by evaluating their likely consequences for personal or collective objectives, conscious that other actors are doing likewise." A logic of appropriateness, by contrast, imagines that actors "follow rules that associate particular identities to particular situations, approaching individual opportunities for action by assessing similarities between current identities and choice dilemmas and more general concepts of self and situations."20

These two logics serve as useful heuristics. Social constructivist accounts in the tradition of Barnett and Finnemore manifest a logic of appropriateness. These perspectives highlight that decision-making in IO s is influenced by rules, identities, role understandings, and the (self-)perception of the bureaucrat as an authority in a particular field. The logic of appropriateness does not tell us, however, if appropriate behavior lies in the exercise of a professional ethos (in one's area of expertise) or in simply doing one's job in a rigid command and control hierarchy. Especially in the former case, this constitutes a form of

\footnotetext{
14 Ege and Bauer 2017.

15 Hooghe et al. 2017, figure 3.1.

16 Stone and Moloney 2019.

17 Barnett and Finnemore 1999, 2004.

18 For this distinction, see Rittberger et al. 2019, 13 ff.; Bauer, da Conceição-Heldt, and Ege 2015. Beyond IR, too, there is a growing interdisciplinary debate; see Eckhard and Ege 2016.

19 Risse 2000, 3.

$20 \quad$ March and Olsen 1998, 949-951.
} 
behavior in which bureaucrats aim to orient their actions toward the collective goals of their IO. This type of behavior is characterized by voluntary subordination and sensitivity to political preferences, but also by an entrepreneurial spirit to find solutions that fit the mandate of the IO.

By contrast, (neo)institutionalists usually build on institutional economics ${ }^{21}$ and, in particular, the principal-agent approach. ${ }^{22}$ The latter does not make direct claims about what bureaucrats want when they do their job. Rather, it still requires a complementary theory that "fills in" the preferences of both principal(s) and agent, ${ }^{23}$ wherein neoinstitutionalists acknowledge that formal and informal institutions shape individual preferences. ${ }^{24}$ Nevertheless, the neoinstitutionalist focus on rational utility calculations, information asymmetries, the danger of slacking behavior (including both shirking and slippage), and moral hazard (as a consequence of delegation) reflects the assumption that bureaucrats act according to a logic of expected consequences. Under this logic, however, it is not clear whether individuals consider the expected "consequences for personal or collective objectives" 25 as the basis for their behavior. In fact, both logics remain neutral with regard to the goal orientation of the actor at hand.

A look at empirical IPA research confirms that neither logic makes an explicit claim about an actor's underlying goal orientation. Following a logic of appropriateness, for instance, does not mean that bureaucratic action will necessarily align with the mandate of their organization. Rather, organizational cultures can make bureaucrats self-centered and insulated; they can lose sight of their initial assignments and broader goals. Here, Barnett and Finnemore identify five well-known bureaucratic pathologies: "the irrationality of rationalization, universalism, normalization of deviance, organizational insulation, and cultural contestation." ${ }^{26}$ Similarly, while neoinstitutionalist accounts, based on a logic of expected consequences, do not necessarily expect shirking, they acknowledge that autonomous secretariats can reduce the negative external effects of self-interested preferences among individual member states. This requires mechanisms of control, to realign the individual interests and organizational mandates, and enable IPA s to foster solutions in the common interest

\footnotetext{
21 North 1990.

22 Hawkins et al. 2006a.

23 Hawkins et al. 2006b, 7.

24 March and Olsen 1984.

25 March and Olsen 1998, 949 (emphasis added).

26 Barnett and Finnemore 1999, 719.
} 
of all member states. ${ }^{27}$ These arguments highlight that both neoinstitutionalist and constructivist thinking (each being based on different behavioral logics) are generally open with regard to the particular reference point of bureaucrats' actions, and do not assume these actions to be oriented ex ante toward either collective or personal goals. ${ }^{28}$

To sum up, contrasting the two logics clearly shows that while it is controversial whether bureaucratic action is the result of an assessment of the underlying payoffs (logic of expected consequences) or a following of identity and norms (logic of appropriateness), both conceptions highlight that bureaucratic behavior is not fully idiosyncratic but that it reflects a more general underlying. However, the juxtaposition also shows that neoinstitutionalist and constructivist thinking are less explicit about the underlying goal orientation of the bureaucracy. Neither logic specifies the reference point for international bureaucrats-Is it the individual bureaucrats themselves, or a larger collective in the form of the IO's member states?

To enhance understanding of the nature of bureaucratic preferences, we must better relate the two behavioral logics to the underlying goal orientation of bureaucratic action. In the next section, I discuss different conceptualizations of bureaucratic goal orientation from the perspective of domestic public administration research to adapt them to international bureaucracies.

\section{3}

\section{Bureaucratic Goal Orientation in Public Administration Research}

The nature of administrative preferences and their behavioral consequences have long been a central topic in PA research, reflecting that the bureaucracy is not simply an instrument that neutrally applies predefined political decisions. ${ }^{29}$ This view was clearly visible in Max Weber's expressed fear of unchecked bureaucratic rule ("Beamtenherrschaft") ${ }^{30}$ and also in warnings

27 Hawkins et al. 2006b, 13-29; da Conceição-Heldt 2017.

28 To clarify the notion of goals here: goal-driven behavior is often associated with a logic of consequences, whereas a logic of appropriateness assumes identity-driven behavior. When I refer to bureaucrats' "goal orientation" under a logic of appropriateness in this article, it is under the assumption that this orientation is shaped by identities and social norms and that the individual is often not directly aware of the underlying reference point of their actions. Therefore, to provide a common terminology, the notion of goal orientation can be used here to discuss the behavioral orientation under both a logic of consequences and appropriateness.

29 Wilson 1941; for details, see Sager and Rosser 2009.

30 This fear was a consequence of Weber's realistic view on the world, whereas his ideal- 
against "bureaucratization" as the "growing acquisition of unregulated power by these organizations, their increasing regimentation and domination of vast areas of social life and their use of such power for their own benefits and goals." ${ }^{31}$ At the same time, however, these accounts emphasized the functional merits of bureaucracy in implementing policy and exercising legal authority. ${ }^{32}$ These two contrasting points served as a basic orientation for subsequent research. While Weber's notion of bureaucracy as an ideal-typically apolitical and efficient tool of governments was particularly formative for mainstream PA research (especially in an Anglo-American context), a non-Weberian perspective characterized the bureaucracy as a political integrator. ${ }^{33}$ Among the abundant contemporary empirical research on the nature of administrative preferences, one may identify two traditional vantage points for assessing bureaucratic preferences in PA research: collective interest versus selfinterest.

The first perspective assumes a collective goal orientation and is based on a conception of bureaucracy as a highly efficient type of (legitimate) government. ${ }^{34}$ However, it goes beyond the purely instrumental understanding of bureaucracy (per Weber's ideal type conception) by attributing to the administration a political role. This role extends beyond administrative accountability (vis-à-vis executive leaders and parliament) and hierarchical subordination to include a sense of responsibility, especially to citizens and society at large. ${ }^{35}$ This perspective also emphasizes the ability of public administrations to work as political integrators with regard to challenging societal groups. ${ }^{36}$ Proponents of this view argue that administrative preferences reflect the shared interest of society. By way of empirical examples, Morten Egeberg argues that the selfinterest of the administration in substantial policy matters is generally low and, thus, the danger of bureaucratic rule is often overestimated. ${ }^{37}$ Edward C. Page provides empirical evidence for this. In his analysis of bureaucratic decrees, he found that, even if bureaucrats have high degrees of discretion, they "do not make policy according to their own preferences but on the basis of distinc-

type conception of bureaucracy should be understood as a conceptual tool rather than a description of reality. Mayntz 1965, 494.

31 Eisenstadt 1958, 103; see also Mayntz 1978, 66.

32 Eisenstadt 1958, 103; Weber 1978, 216.

33 For an overview, see Seibel 2010.

34 Weber 1978; Wilson 1941.

35 Friedrich 1940; for a different view, see Finer 1941.

36 Seibel 2010; Kaufman 196o.

37 Egeberg 1995 . 
tive conceptions of bureaucratic roles and within a host of normative and legal constraints." ${ }^{38}$ Viewing bureaucratic preferences from the angle of professionalism and bureaucratic ethos is also prominent in research that investigates the degree to which public servants share particular values, what motivates them in their work, and why they choose to work in the public sector in the first place. ${ }^{39}$

The second perspective assumes a self-centered goal orientation, and in its purest form considers bureaucrats as utility-maximizing and rent-seeking individuals. This view is strongly influenced by early economic accounts of bureaucracy ${ }^{40}$ and the public choice school. ${ }^{41}$ Antony Downs provides the exemplary model for such an economic account of bureaucracy. In his seminal book Inside Bureaucracy, self-interest in the form of power and prestige is the most important driver of bureaucratic behavior. ${ }^{42}$ Of the five bureaucratic types that Downs describes, "climbers" and "conservers" act purely out of self-interest. While "climbers" aim to further maximize their own power and prestige, "conservers" feel they have already achieved enough and invest their efforts in maintaining their degree of power and prestige. The remaining three types of bureaucrats do not act purely self-interestedly, but mix their own self-interested motives with "altruistic loyalty to larger values." ${ }^{33}$ Viewing bureaucrats as utility-maximizers in this way has provided the basis for developing widely used concepts such as slack and moral hazard, which are seen as an inevitable consequence of the delegation of tasks to the administration. ${ }^{44}$ These concepts also offered ways to avoid undesired consequences such as bureaucratic drift ${ }^{45}$ by tightening bureaucratic control. ${ }^{46}$ While early conceptions of bureaucratic self-interest were focused primarily on budgetmaximization efforts, ${ }^{47}$ scholars have subsequently developed more nuanced models, such as bureau-shaping strategies, to capture what bureaucrats want. ${ }^{48}$

In the next section, I apply these two kinds of goal orientation to international bureaucracies and discuss how a combination of these goal orientations

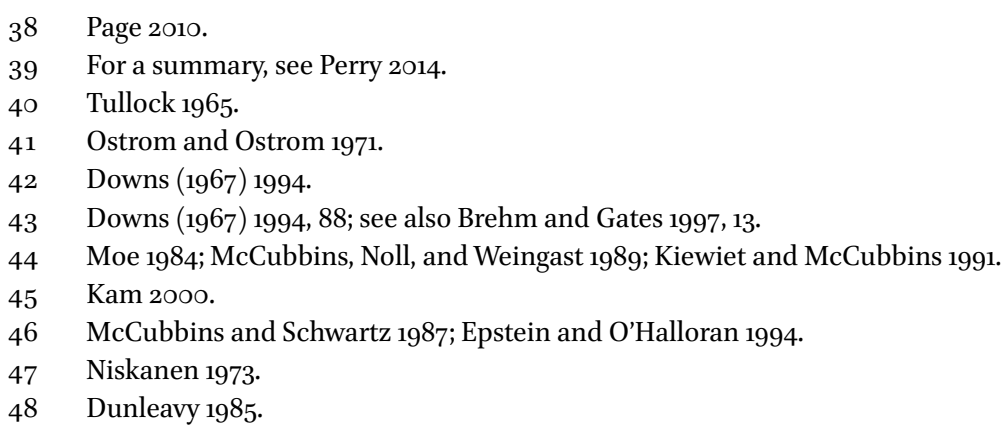


with the two logics of action can help us to cluster current IPA research into four ideal types of bureaucratic behavior.

\section{$4 \quad$ Four Ideal Types of Bureaucratic Behavior}

As demonstrated in the previous section, PA research traditionally views the preferences of bureaucrats as located on a continuum between collective and self-centered goal orientation. This basic differentiation can also be found in IR research. For example, Mark S. Copelovitch puts forward a model of goal orientation among IMF staff that emphasizes both policy goals (collective goal orientation) and bureaucratic incentives (individual-centered goal orientation) as central reference points of bureaucratic behavior. He argues that

above all, staff members are economists and civil servants interested in achieving the IMF's [International Monetary Fund's] policy objectives ... At the same time, public choice theorists emphasize the staff's bureaucratic incentives to propose larger loans with more conditions, to maximize its budget, autonomy, and influence. Although scholars differ over the relative importance of each of these objectives, both factors are likely to influence IMF staff preferences. ${ }^{49}$

Here, in contrast to the behavioral logics, the question of goal orientation is more closely related to the desirability of autonomous bureaucratic behavior. Does it result in problem-solving that leads to more effective policy solutions, or to self-centered and inward-looking behavior that is conducive to suboptimal outcomes?

Because behavioral logics and bureaucratic goal orientation are independent of each other, and thus need to be considered separately, they can be combined into a $2 \times 2$ table. As can be seen from Figure 1, each cell of this table represents one of four ideal types of bureaucratic behavior.

Of course, individual bureaucrats are not bound to behave in only one particular way. Instead, they can engage (intentionally or unintentionally) in various types of behavior-depending on the particular situation and political constellation. For this reason, these four types of behavior should be viewed as ideal types, which provide an analytic standard against which real-world behav- 


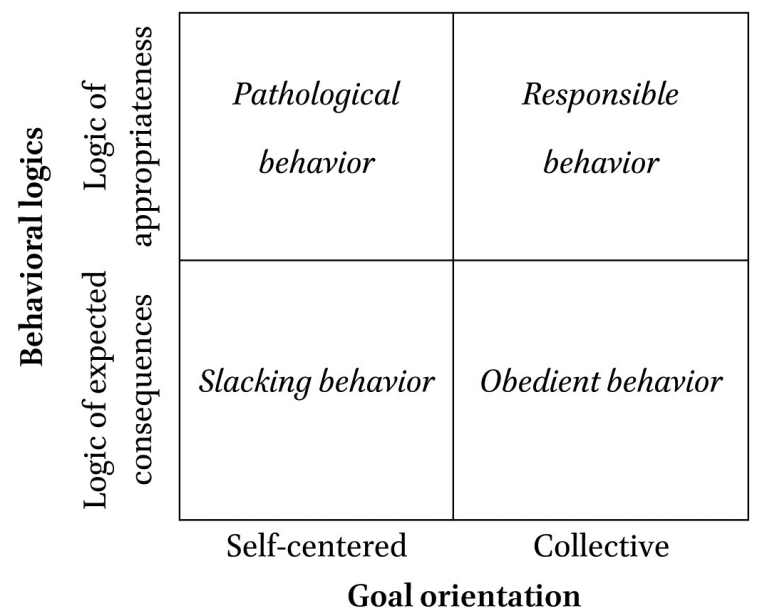

FIGURE 1

Four ideal types of bureaucratic behavior

ior can be compared.$^{50}$ I use them here to categorize existing studies to bring more clarity to the question of bureaucratic preferences in IO research. First, however, I briefly describe each type of behavior and embed it in IO research.

\subsection{Responsible Behavior}

Responsible behavior describes bureaucratic action conforming to a logic of appropriateness and intended to advance the collectively agreed-on mandate of the IO. Bureaucrats acting responsibly are often intrinsically motivated by a sense of professionalism and a public service ethos. They are less driven by self-centered motives such as personal career advancement. Voluntary subordination and political sensitivity to the preferences of the (collective) of member states, and their hierarchical superiors, characterize this type of behavior. At the same time, responsible behavior also requires international bureaucracies to act entrepreneurially, to advance policies that help the IO to achieve its mandate. In early works on the international civil service, this type of behavior was the default assumption regarding $\mathrm{UN}$ civil servants. ${ }^{51} \mathrm{It}$ is also prominent in (neo)functional perspectives on global governance ${ }^{52}$ as well as in recent studies of international environmental bureaucracies as problem-solvers. ${ }^{53}$

5 O Peters 1996, 29.

$51 \quad$ Langrod 1963; Weiss 1975; Beigbeder 1988.

52 E.B. Haas 1964; P.M. Haas 1992.

53 Biermann and Siebenhüner 2009. 


\subsection{Pathological Behavior}

Pathological behavior is characteristic of bureaucrats who act according to a logic of appropriateness, but follow noncollective goals. ${ }^{54}$ Noncollective goal orientation comes in different forms. Bureaucratic goals may benefit the bureaucracy itself (in whole or in part), individual states, or third parties. This behavior is described in works that emphasize the propensity of IO staff to act in a "siloed" fashion, leading to organizational compartmentalization. Jarle Trondal shows how international bureaucrats may "orient their behaviour towards their present ... units rather than to the concerns of member state governments," giving rise to “'inward-looking' behavioural patterns geared towards their 'own' sub-units and task environments." 55 Similarly, Barnett and Finnermore describe how "competition among subunits over material resources leads the organization to make decisions and engage in behaviors that are inefficient or undesirable as judged against some ideal policy that would better allow the IO to achieve its stated goals." ${ }^{56}$ Other forms of pathological behavior are described as the "irrationality of rationalization." 57 They emerge when bureaucratic means become ends in themselves, or when the administration becomes "captured" by outside interest. ${ }^{58}$

\subsection{Obedient Behavior}

Bureaucrats who engage in obedient behavior generally follow a logic of expected consequences. But in contrast to slacking bureaucrats (see below), obedient bureaucrats know that they are under close scrutiny from their political principals and other stakeholders. ${ }^{59}$ This leads to a realignment of bureaucratic interests toward the collective goal of the organization, rendering IPA behavior in essence mandate oriented. Under this mode autonomous behavior is possible, and even intended through the explicit establishment of discretion by the political leadership (to maximize the benefits of delegation). But autonomous action occurs within certain bounds, as delegated to the administration, ${ }^{60}$ consistent with the goals of the organization and its members.

\footnotetext{
54 "Appropriateness" here refers to the underlying behavioral logic (per March and Olsen 1984) and does not imply that behavior is normatively or objectively appropriate.

55 Trondal 2017, 40.

56 Barnett and Finnemore 1999, 716-717.

57 Barnett and Finnemore 1999, 719.

58 Dal Bo 2006.

59 Lyne, Nielson, and Tierney 2006.

6o Haftel and Thompson 2oo6; Hawkins et al. 20o6b, 8.
} 


\subsection{Slacking Behavior}

Slacking behavior is expected if bureaucrats follow a logic of expected consequences and demonstrate a goal orientation that is primarily self-centered. Moreover, it is assumed that slacking bureaucrats are not sufficiently controlled by the member states and their permanent representations. Slacking behavior is the standard model of administrative behavior in economics-oriented public choice research on IO s. ${ }^{61}$ While some scholars in this tradition suggest that bureaucracies are primarily interested in "power, prestige and amenities,"62 more recent scholarship includes decisions that are not "economically optimal and technocratic, but ... reflect the bureaucracy's particular interests and beliefs." ${ }^{63}$ Generally, a self-centered goal orientation is reflected in all bureaucratic actions that do not serve the purpose of the organization. This is also the case if the administration is "captured" by special interests. ${ }^{64}$ This happens, for instance, if an IO's staff gets too closely involved with third parties on the ground, or acts in the interest of individual member states. ${ }^{65}$

It is important to keep in mind that even though behavioral logics and goal orientations are considered conceptually independent, one would not expect all their combinations to be equally likely in empirical research. Based on the theoretical affinity of certain combinations, it seems intuitive to expect that a given a logic of appropriateness is more closely associated with a collective goal orientation. Similarly, if a study builds on a logic of expected consequences, it seems more likely that the bureaucracy will show signs of self-centered behavior. Thus, responsible behavior and slacking behavior should be the two types that are most prevalent in empirical research.

In sum, the behavior of international bureaucrats in IOs is more complex than the distinction between the two behavioral logics and the major fault lines of IR theorizing suggest. This is neither a new insight nor surprising given the complex nature of human behavior. Yet in the current IO/IPA literature, there seems to be no commonly shared approach to how the behavior of international bureaucrats can be modeled or understood. Relatedly, we also do not know which logics and goal orientations are more prominently used in this literature. Thus, in the next section I provide a selective review

\footnotetext{
$61 \quad$ Frey 1997.

62 Vaubel 1996, 195 .

63 Lang and Presbitero 2018, 1; for a broader overview of the public choice perspective on IOs, see Dreher and Lang 2019.

64 Carpenter and Moss 2013.

65 Urpelainen 2012.
} 
and ask what recent research can tell us about the prevalence of these four types in empirical settings.

\section{$5 \quad$ Applying the Four Ideal Types of Bureaucratic Behavior to IPA Research}

To assess how the IO literature approaches bureaucratic preferences, I undertook a systematic literature review using an established keyword-based selection procedure to build on and bring up to date past research (i.e., by focusing on articles published from 2015 to 2018 in IR and PA journals listed in the "Web of Science"). ${ }^{66}$ Such a temporally restricted search can provide only a snapshot of research efforts at the intersection of IR and PA research. Yet it has the advantages of avoiding repetition and capturing the latest developments in IPA research. The search yielded a total of thirty-nine articles, which provide a sufficient empirical basis for the application of the four ideal types and reflect a thriving field of administration-focused IO studies. For each article, the underlying behavioral logic and the predominant goal orientation of the bureaucracy were coded independently of each other.

\subsection{Prevalence of the Two Behavioral Logics}

I found evidence for a logic of appropriateness in twenty-five studies (64 percent of the sample). This logic was coded as present if the authors emphasized the effect of "institutions" (broadly understood) on bureaucratic behavior. In the sample, this was discussed mainly in articles that studied bureaucratic culture or a Weberian professional ethos, ${ }^{67}$ administrative styles ${ }^{68}$ or the impact of organizational socialization. ${ }^{69}$ By contrast, studies emphasizing a logic of expected consequence (fourteen articles; 36 percent) draw on the principalagent approach to model the relationship between member states and the IPA $^{70}$ or other economically inspired theories of human behavior. ${ }^{71}$

66 See Eckhard and Ege 2016. The present study comprises articles that were not available when that research occurred.

67 Hensell 2016; Steffek 2016.

68 Enkler et al. 2017.

69 Murdoch, Trondal, and Geys 2016.

70 Dijkstra 2017.

$71 \quad$ Lang and Presbitero 2018; Parízek 2016; Manulak 2017. 


\subsection{Prevalence of the Two Goal Orientations}

Assessing bureaucratic goal orientation in the sample was more challenging because in some articles different goal orientations were mentioned. In this case, the most important orientation (either theoretically or empirically supported) was coded. The coding of a collective goal orientation was mostly clearcut and straightforward. This goal orientation was found in twenty-five articles (64 percent). It was particularly prominent in studies building on neofunctionalism or Weber's concept of bureaucracy where international "bureaucrats make decisions not on the basis of arbitrary political will or material interests of office holders but on the basis of formal legal prescriptions". ${ }^{72}$ Relatedly, a collective goal orientation is also prominent in research that is rooted in the PA tradition more broadly. ${ }^{73}$ Sometimes scholars have found that the bureaucracy is (slightly) biased in favor of certain subgroups of membership such as workers' interests in case of the bureaucracy of the International Labour Organization ${ }^{74}$ or least developed countries in case of the UN Secretary-General. ${ }^{75}$ Even though these studies tend to show characteristics of a noncollective goal orientation, they are still considered "collective" because privileging disadvantaged groups in this way is found to be in line with the general IO mandate.

Regarding the self-centered goal orientation, however, the literature provides a more diverse picture. Coding the articles resulted in three different reference points that could be defined as self-centered goal orientation. On the one hand, the "self" may refer to the bureaucracy, which is clear-cut. One the other hand, there are also articles that refer to member state and third-party interests that the bureaucracy incorporated into their own behavior. Table 1 summarizes these different kinds of self-centered goal orientation and provides examples from the sample articles.

Surprisingly, the number of articles that highlight the relevance of material personal gains for individual bureaucrats is low and less relevant than one would expect from the prominence of this view in the academic and public debate. For instance, Tana Johnson theorizes the goal orientation of individual staff members. While she found the collective (ideational) goal orientation more important, she acknowledges that one of the reasons why IO staff cooperate with nongovernmental organizations is because it "increases well-paid posts for international bureaucrats and necessitates further organizational

72 Weber 1978, 958 cited in Steffek 2016, 1504.

73 Mele, Anderfuhren-Biget, and Varone 2016; Knill and Bauer 2016.

74 Thomas and Turnbull 2018.

75 Haack 2018. 
TABLE 1 Types of self-centered goal orientation identified in international public administration (IPA) research

$\begin{array}{lll}\begin{array}{l}\text { Type of self-centered goal ori- } \\ \text { entation and reference points }\end{array} & \begin{array}{l}\text { Consequence of self-centered } \\ \text { goal orientation }\end{array} & \text { Illustrative article(s) }\end{array}$

\begin{tabular}{|c|c|c|c|}
\hline \multirow[t]{3}{*}{ Bureaucracy } & Whole IPA & Mission creep & Littoz-Monnet 2017 \\
\hline & $\begin{array}{l}\text { Administrative } \\
\text { unit }\end{array}$ & Departmentalization & $\begin{array}{l}\text { Reinsberg } 2017 \\
\text { Mahon } 2018\end{array}$ \\
\hline & Individual staff & $\begin{array}{l}\text { Individual material gains (jobs, } \\
\text { career advancement, security) }\end{array}$ & Brachet 2016 \\
\hline \multirow[t]{2}{*}{$\begin{array}{l}\text { Individual } \\
\text { states }\end{array}$} & Powerful states & $\begin{array}{l}\text { Unilateral influence on IPA } \\
\text { (often informal) }\end{array}$ & $\begin{array}{l}\text { Manulak } 2017 \\
\text { Eckhard and Dijkstra } 2017 \\
\text { Kleine } 2018\end{array}$ \\
\hline & $\begin{array}{l}\text { Staff's home } \\
\text { country }\end{array}$ & $\begin{array}{l}\text { Representative bureaucracy } \\
\text { (including secondment) }\end{array}$ & $\begin{array}{l}\text { Murdoch, Trondal, and } \\
\text { Geys } 2016 \\
\text { Christensen, van den } \\
\text { Bekerom, and van der Voet } \\
2017\end{array}$ \\
\hline
\end{tabular}

Third

Local interests Privileging special interest

Burns et al. 2017

parties groups

Duclos 2016

resources and machinery."76 In a similar vein, Julien Brachet critically observes that the discourse surrounding the management of the international migration crises is geared toward the creation of "jobs for a new international elite of experts." 77 By contrast, more prominent expressions of self-centered behavior using the bureaucracy as a reference point usually focus on the IPA as a whole ${ }^{78}$ or individual subunits. ${ }^{79}$ Research that is oriented toward the interest of individual states is prominent in two strands of research. First, this is found

\footnotetext{
76 Johnson 2016, 741 .

77 Brachet 2016, 287.

78 Littoz-Monnet 2017.

79 Reinsberg 2017.
} 


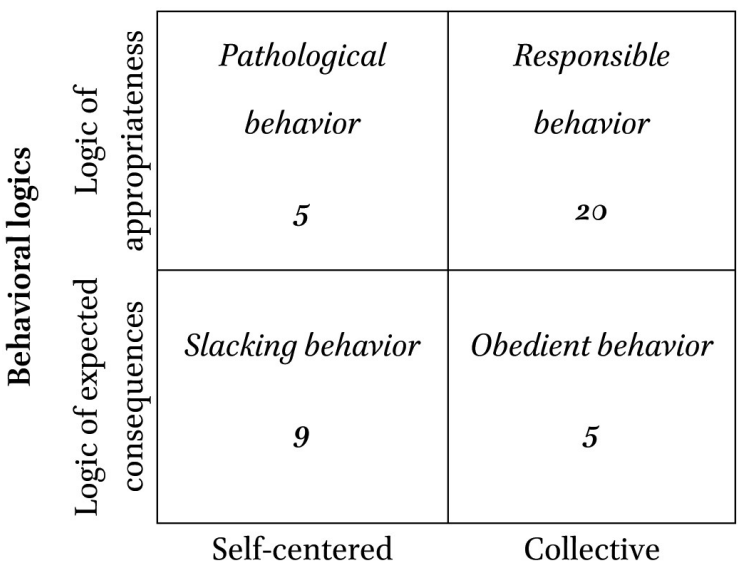

Goal orientation
FIGURE 2

Empirical relevance of the four ideal types of bureaucratic behavior Note: Strength of association: chi-square $=7.6488, p=$ o.oo6.

in studies of (often informal) unilateral influence of states on the IPA, which has gained pace over the past years. ${ }^{80}$ For instance, Valentin F. Lang and Andrea F. Presbitero found that World Bank and IMF staff are biased in their risk assessment of borrowing countries. ${ }^{81}$ They argue that when using bureaucratic discretion within the Debt Sustainability Framework, staff are more likely to decide in favor of countries that are politically aligned with the institutions' major shareholders. Second, self-centered goal orientation is the underlying behavioral assumption in research that focuses on the effect of staff members' home country. ${ }^{82}$ The nationality of IPA staff has recently gained increasing attention in research on representative bureaucracy, especially in the European Union context. ${ }^{83}$ Finally, scholars are concerned with IPA actions privileging special interest groups such as former combatants in UN peace missions ${ }^{84}$ or business interests in natural resource management. ${ }^{85}$

\subsection{Prevalence of the Four Ideal Types}

Based on the coding of the two dimensions, the bureaucratic behavior displayed in each article can be categorized as one of the four ideal types. This allows us to assess the empirical prevalence of each type. Figure 2 shows that the most frequently described type is "responsible behavior" with half the

\footnotetext{
8o $\quad$ Eckhard and Dijkstra 2017; Kleine 2018.

$81 \quad$ Lang and Presbitero 2018.

82 Parízek 2016.

83 Murdoch, Trondal, and Geys 2016; Christensen, van den Bekerom, and van der Voet 2017.

84 Duclos 2016.

85 Burns et al. 2017 .
} 
sample (twenty articles) taking this perspective. About a quarter of publications (nine articles) describe "slacking behavior." With five articles each, "obedient behavior" and "pathological behavior" are less frequent, but still empirically identifiable as individual combinations.

Figure 2 also shows that the empirical research confirms the intuitive association between, on the one hand, a logic of appropriateness and a collective goal orientation and, on the other, a logic of expected consequences and self-centered behavior. This relationship is statistically significant $(p$-value $=$ o.oo6) but not fully deterministic, of course. Instead, treating behavioral logics and goal orientation as conceptually independent also bears importance in the empirical world. The "hybrid" cases of pathological behavior and obedient behavior together still account for as much as a quarter of all articles.

\section{Conclusions}

The typology proposed in this article enables us to map the prevalence of different bureaucratic behavioral logics and goal orientations described in the most recent research output published in the top-ranking journals in IR and PA. Applying the typology to these thirty-nine articles shows that a collective goal orientation is used twice as much as a self-centered goal orientation. The same can be concluded regarding the dominance of the logic of appropriateness over the logic of expected consequences. Taken together, this indicates that in contrast to economic accounts of bureaucracy, recent research in IR and PA views IPAs predominantly as behaving responsibly.

These results allow us to leverage the ideal typology, indicating the relative empirical importance of different views of bureaucracy and enabling comparison of different types of preferences in IO research. Of course, not all the studies considered here provide empirical-analytical conclusions about behavioral logic and goal orientation. Some deduce bureaucratic preferences from theoretical considerations. Nevertheless, to my knowledge, this article is the first attempt to systematically gather information on how the preferences of IPAs are studied in current research.

For future IO research, adequately conceptualizing the preferences and resulting behavior of IPAs is an important challenge. Yet the more international bureaucracies are seen as autonomous and influential actors in global politics, ${ }^{86}$ the more important it becomes to include their preferences in empir-

86 Knill et al. 2019; Biermann and Siebenhüner 2009; Cox and Jacobson 1973; Ege, Bauer, and Wagner 2019. 
ical influence research. The prominence of responsible behavior in IPA research, which is clearly the most important finding of this review, directly challenges self-centered goal orientation as the default mode of bureaucratic behavior. This indicates that scholars studying the role of bureaucrats in world politics may need to recalibrate the assumed preferences of bureaucrats or should at least be more empirically open to their particular nature. What is more, since behavior is not always the most reliable way to deduce the nature of preference, future research on the internal dynamics of IO policy-making could also capitalize on recent advancements in behavioral public policy and administration ${ }^{87}$ and rely more on experiments to determine the guiding principles of international civil servants' actions.

\section{Bibliography}

Barnett, Michael, and Martha Finnemore. "The Politics, Power, and Pathologies of International Organizations." International Organization 53 (4) (1999), 699-732.

Barnett, Michael, and Martha Finnemore. Rules for the World: International Organizations in Global Politics (Ithaca: Cornell University Press, 2004).

Bauer, Michael W., Eugénia da Conceição-Heldt, and Jörn Ege. "Autonomiekonzeptionen Internationaler Organisationen im Vergleich." Politische Vierteljahresschrift 49 (2015), 28-53.

Beigbeder, Yves. Threats to the International Civil Service-Past Pressures and New Trends. (London: Pinter, 1988).

Biermann, Frank, and Bernd Siebenhüner, eds. Managers of Global Change: The Influence of International Environmental Bureaucracies (Cambridge: MIT Press, 2009).

Brachet, Julien. "Policing the Desert: The IOM in Libya Beyond War and Peace." ANTIPODE 48 (2) (2016), 272-292. DOI 10.111/anti.12176.

Brehm, John, and Scott Gates. Working, Shirking, and Sabotage (Ann Arbor: University of Michigan Press, 1997). DOI 10.3998/mpub.15149.

Burns, Sarah L., Max Krott, Hovik Sayadyan, and Lukas Giessen. "The World Bank Improving Environmental and Natural Resource Policies: Power, Deregulation, and Privatization in (Post-Soviet) Armenia." World Development 92 (2017), 215-224. DOI 10.1016/j.worlddev.2016.12.030.

Carpenter, Daniel, and David A. Moss, eds. Preventing Regulatory Capture: Special Interest Influence and How to Limit It (Cambridge: Cambridge University Press, 2013).

Christensen, Johan, Petra van den Bekerom, and Joris van der Voet. "Representative

87 See, for instance James, Jilke, and van Ryzin 2017. 
Bureaucracy and Specialist Knowledge in the European Commission." Public Administration 95 (2) (2017), 450-467. DOI 10.1111/padm.12314.

Copelovitch, Mark S. "Master or Servant? Common Agency and the Political Economy of IMF Lending." International Studies Quarterly 54(1) (2010), 49-77. DOI 10.1111/j.146 8-2478.2009.00577.x.

Cox, Robert W. "The Executive Head: An Essay on Leadership in International Organization." International Organization 23 (2) (1969), 205-23o.

Cox, Robert W., and Harold K. Jacobson. The Anatomy of Influence: Decision Making in International Organization (New Haven: Yale University Press, 1973).

da Conceição-Heldt, Eugénia. "Regaining Control of Errant Agents? Agency Slack at the European Commission and the World Health Organization." Cooperation and Conflict 48 (5) (2017), o01083671770367. DOI 10.1177/o010836717703673.

Dal Bo, E. "Regulatory Capture: A Review." Oxford Review of Economic Policy 22 (2) (2006), 203-225. DOI 10.1093/oxrep/grjo13.

Dijkstra, Hylke. "Collusion in International Organizations: How States Benefit from the Authority of Secretariats." Global Governance 23 (4) (2017), 6o1-618. DOI 10.5555/107 5-2846.23.4.6o1.

Downs, Anthony. Inside Bureaucracy (Prospect Heights, IL: Waveland Press, [1967] 1994).

Dreher, Axel, and Valentin F. Lang. "The Political Economy of International Organizations." In The Oxford Handbook of Public Choice, eds. Roger D. Congleton, Bernard N. Grofman, and Stefan Voigt (Oxford: Oxford University Press, 2019), 6o6-652.

Duclos, Nathalie. "The DDR in Kosovo: Collision and Collusion among International Administrators and Combatants." Peacebuilding 4(1) (2016), 41-53. DOI 10.1080/2164 7259.2015.109926o.

Dunleavy, Patrick. "Bureaucrats, Budgets and the Growth of the State: Reconstructing an Instrumental Model." British Journal of Political Science 15 (3) (1985), 299328.

Eckhard, Steffen, and Hylke Dijkstra. "Contested Implementation: The Unilateral Influence of Member States on Peacebuilding Policy in Kosovo." Global Policy 8 (2017), 102-112. DO I 10.1111/1758-5899.12455.

Eckhard, Steffen, and Jörn Ege. "International Bureaucracies and Their Influence on Policy-Making: A Review of Empirical Evidence." Journal of European Public Policy 23 (7) (2016), 96o-978. DOI 10.108o/13501763.2016.1162837.

Ege, Jörn, and Michael W. Bauer. "How Financial Resources Affect the Autonomy of International Public Administrations." Global Policy 8 (2017), 75-84. DOI 10.1111/17585899.12451 .

Ege, Jörn, Michael W. Bauer, and Nora Wagner. "Improving Generalizability in Transnational Bureaucratic Influence Research: A (Modest) Proposal." International Studies Review 95 (3) (2019), 1-25. DOI 10.1093/isr/vizo26. 
Egeberg, Morten. "Bureaucrats as Public Policy-Makers and Their Self-Interests." Journal of Theoretical Politics 7 (2) (1995), 157-167.

Eisenstadt, S.N. "Bureaucracy and Bureaucratization." Current Sociology 7 (2) (1958), 99-124. DOI 10.1177/oo1139215800700201.

Enkler, Jan, Sylvia Schmidt, Steffen Eckhard, Christoph Knill, and Stephan Grohs. "Administrative Styles in the OECD: Bureaucratic Policy-Making beyond Formal Rules: Bureaucratic Policy-Making beyond Formal Rules." International Journal of Public Administration 40 (8) (2017), 637-648. DOI 10.108o/o19oo692.2016.1186176.

Epstein, David, and Sharyn O'Halloran. "Administrative Procedures, Information, and Agency Discretion." American Journal of Political Science 38 (3) (1994), 697-722.

Finer, Herman. "Administrative Responsibility in Democratic Government." Public Administration Review 1 (4) (1941), 335-350. DOI 10.2307/972907.

Finnemore, Martha. "International Organizations as Teachers of Norms: The United Nations Educational, Scientific and Cultural Organization and Science Policy." International Organization 47 (4) (1993), 565-597.

Frey, Bruno S. "The Public Choice of International Organizations." In Perspectives on Public Choice: A Handbook, ed. Dennis C. Mueller (New York: Cambridge University Press, 1997), 106-148.

Friedrich, Carl J. "Public Policy and the Nature of Administrative Responsibility." In Public Policy: A Yearbook of the Graduate School of Public Administration, eds. Carl J. Friedrich and Edward S. Mason (Cambridge: Harvard University Press, 1940), 324.

Haack, Kirsten. "The UN Secretary-General, Role Expansion and Narratives of Representation in the 2016 Campaign." British Journal of Politics and International Relations 20 (4) (2018), 898-912. DOI 10.1177/1369148118784706.

Haas, Ernst B. Beyond the Nation-State: Functionalism and International Organization (Palo Alto: Stanford University Press, 1964).

Haas, Peter M. "Introduction: Epistemic Communities and International Policy Coordination." International Organization 46 (1) (1992), 1-35.

Haftel, Yoram Z., and Alexander Thompson. "The Independence of International Organizations - Concept and Applications." Journal of Conflict Resolution 5o (2) (2006), 253-275.

Hawkins, Darren G., David A. Lake, Daniel L. Nielson, and Michael J. Tierney, eds. Delegation and Agency in International Organizations (Cambridge: Cambridge University Press, 2006a).

Hawkins, Darren G., David A. Lake, Daniel L. Nielson, and Michael J. Tierney. "Delegation Under Anarchy-States, International Organizations, and Principal-Agent Theory." In Delegation and Agency in International Organizations, eds. Darren G. Hawkins, David A. Lake, Daniel L. Nielson, and Michael J. Tierney (Cambridge: Cambridge University Press, 2006b), 3-38. 
Hensell, Stephan. "Staff and Status in International Bureaucracies: A Weberian Perspective on the EU Civil Service." Cambridge Review of International Affairs 29 (4) (2016), 1486-1501. DOI 10.108o/o9557571.2015.1118995.

Hooghe, Liesbet, Gary Marks, Tobias Lenz, Jeanine Bezuijen, Besir Ceka, and Svet Derderyan. Measuring International Authority: A Postfunctionalist Theory of Governance, vol. 3 (Oxford: Oxford University Press, 2017).

James, Oliver, Sebastian R. Jilke, and Gregg G. van Ryzin. "Behavioural and Experimental Public Administration: Emerging Contributions and New Directions." Public Administration 95 (4) (2017), 865-873. DOI 10.1111/padm.12363.

Johnson, Tana. "Looking beyond States: Openings for International Bureaucrats to Enter the Institutional Design Process." Review of International Organizations 8 (4) (2013), 499-519. DOI 10.1007/s11558-o13-9166-o.

Johnson, Tana. "Cooperation, Co-optation, Competition, Conflict: International Bureaucracies and Non-governmental Organizations in an Interdependent World." Review of International Political Economy 23 (5) (2016), 737-767. DOI 10.108o/og6922 90.2016.1217902.

Kam, Christopher. “Not Just Parliamentary 'Cowboys and Indians': Ministerial Responsibility and Bureaucratic Drift." Governance 13 (3) (2000), 365-392. DOI 10.1111/o9521895.00138.

Kaufman, Herbert. The Forest Ranger: A Study in Administrative Behavior (Baltimore: Johns Hopkins University Press, 196o).

Kiewiet, D. Roderick, and Mathew D. McCubbins. The Logic of Delegation-Congressional Parties and the Appropriations Process (Chicago: University of Chicago Press, 1991).

Kleine, Mareike. "Keeping Tabs on Your Cooperating Partners: A Coalition Perspective on International Organizations." International Theory 3 (2018), 1-24. DOI 10.1017/S17 52971918000106.

Knill, Christoph, and Michael W. Bauer. "Policy-Making by International Public Administrations - Concepts, Causes and Consequences: Introduction to the Special Issue: Governance by International Public Administrations? Tools of Bureaucratic Influence and Effects on Global Public Policies." Journal of European Public Policy 23 (7) (2016), 949-959. DOI 10.108o/13501763.2016.1168979.

Knill, Christoph, Louisa Bayerlein, Jan Enkler, and Stephan Grohs. "Bureaucratic Influence and Administrative Styles in International Organizations." Review of International Organizations 14 (1) (2019), 83-106. DOI 10.1007/s11558-018-9303-x.

Lang, Valentin F., and Andrea F. Presbitero. "Room for Discretion? Biased DecisionMaking in International Financial Institutions." Journal of Development Economics 130 (2018), 1-16. DOI 10.1016/j.jdeveco.2017.09.001.

Langrod, Georges. The International Civil Service: Its Origins, Its Nature, Its Evolution. (Leyden: A.W. Sythoff, 1963). 
Littoz-Monnet, Annabelle. "Expert Knowledge as a Strategic Resource: International Bureaucrats and the Shaping of Bioethical Standards." International Studies Quarterly 61 (2017), 584-595. DOI 10.1093/isq/sqxo16.

Lyne, Mona M., Daniel L. Nielson, and Michael J. Tierney. "Who Delegates? Alternative Models of Principals in Development Aid." In Delegation and Agency in International Organizations, eds. Darren G. Hawkins, David A. Lake, Daniel L. Nielson, and Michael J. Tierney (Cambridge: Cambridge University Press, 2006), 41-76.

Mahon, Rianne. "Through a Fractured Gaze: The OECD, the World Bank and Transnational Care Chains." Current Sociology 66 (4) (2018), 562-576. DOI 10.1177/oo11392118 765214.

Manulak, Michael W. "Leading by Design: Informal Influence and International Secretariats." Review of International Organizations 12 (4) (2017), 497-522. DOI 10.1007/s115 58-016-9245-o.

March,James G., and Johan P. Olsen. “The New Institutionalism: Organizational Factors in Political Life." American Political Science Review 7 (3) (1984), 734-749.

March, James G., and Johan P. Olsen. “The Institutional Dynamics of International Political Orders." International Organization $5^{2}$ (4) (1998), 943-969.

Marcussen, Martin, and Jarle Trondal. "The OECD Civil Servant: Caught between Scylla and Charybdis." Review of International Political Economy 18 (5) (2011), 592-621. DOI 10.1080/og692290.2011.603665.

Mayntz, Renate. "Max Webers Idealtypus der Bürokratie und die Organisationssoziologie." Kölner Zeitschrift für Soziologie und Sozialpsychologie 17 (1965), 493-502.

Mayntz, Renate. Soziologie der Öffentlichen Verwaltung. (Heidelberg: C.F. Müller, 1978). McCubbins, Matthew D., Roger G. Noll, and Barry R. Weingast. "Structure and Process, Politics and Policy: Administrative Arrangements and the Political Control of Agencies." Virginia Law Review 75 (2) (1989), 431-482. DOI 10.2307/1073179.

McCubbins, Mathew D., and Thomas Schwartz. "Congressional Oversight Overlooked: Police Patrols Versus Fire Alarms." In Congress: Structure and Policy, eds. Mathew D. McCubbins and Terry Sullivan (New York: Cambridge University Press, 1987), 426440.

Mele, Valentina, Simon Anderfuhren-Biget, and Frédéric Varone. "Conflicts of Interest in International Organizations: Evidence from Two United Nations Humanitarian Agencies." Public Administration 94 (2) (2016), 490-508. DOI 10.1111/padm.12228.

Michaelowa, Katharina, and Axel Michaelowa. "The Growing Influence of the UNFCCC Secretariat on the Clean Development Mechanism." International Environmental Agreements: Politics, Law and Economics 17 (2) (2017), 247-269. DOI 10.100 7/s10784-016-9319-8.

Moe, Terry M. "The New Economics of Organization." American Journal of Political Science 28 (4) (1984), 739-777. DOI 10.2307/2110997.

Murdoch, Zuzana, Jarle Trondal, and Benny Geys. "Representative Bureaucracy and 
Seconded National Government Officials in the European Commission." Regulation and Governance 10 (4) (2016), 335-349. DOI 10.1111/rego.12089.

Niskanen, William A. Bureaucracy: Servant or Master? (London: Institute of Economic Affairs, 1973).

North, Douglass C. Institutions, Institutional Change, and Economic Performance: The Political Economy of Institutions and Decisions (Cambridge: Cambridge University Press, 1990).

Ostrom, Vincent, and Elinor Ostrom. "Public Choice: A Different Approach to the Study of Public Administration." Public Administration Review 31 (2) (1971), 203-216.

Page, Edward C. "Bureaucrats and Expertise: Elucidating a Problematic Relationship in Three Tableaux and Six Jurisdictions." Sociologie du Travail $5^{2}$ (2) (2010), 255-273. DOI 10.1016/j.soctra.2010.03.021.

Parízek, Michal. "Control, Soft Information, and the Politics of International Organizations Staffing." Review of International Organizations 12 (4) (2017), 559-583. DOI 10.10 o7/s11558-016-9252-1.

Perry, James L. "The Motivational Bases of Public Service: Foundations for a Third Wave of Research." Asia Pacific Journal of Public Administration 36 (1) (2014), 34-47. DOI 10.1080/23276665.2014.892272.

Peters, B. Guy. "Theory and Methodology." In Civil Service Systems in Comparative Perspective, eds. Hans A.G.M. Bekke, James L. Perry, and Theo A.J. Toonen (Bloomington: Indiana University Press, 1996), 13-41.

Reinalda, Bob, and Bertjan Verbeek, eds. Decision Making within International Organizations (London: Routledge, 2004).

Reinsberg, Bernhard. "Organizational Reform and the Rise of Trust Funds: Lessons from the World Bank." Review of International Organizations 12 (2) (2017), 199-226. DOI 10.1007/s11558-017-9268-1.

Risse, Thomas. “'Let's Argue!' Communicative Action in World Politics.” International Organization 54 (1) (2000), 1-39. DOI 10.1162/002081800551109.

Rittberger, Volker, Bernhard Zangl, Andreas Kruck, and Hylke Dijkstra. International Organization, 3rd ed. (Houndmills: Red Globe Press, 2019).

Sager, Fritz, and Christian Rosser. "Weber, Wilson, and Hegel: Theories of Modern Bureaucracy." Public Administration Review 69 (6) (2009), 1136-1147.

Seibel, Wolfgang. "Beyond Bureaucracy. Public Administration as Integrator and NonWeberian Thought in Germany." Public Administration Review 7o (5) (2010), 719-730.

Steffek, Jens. "Max Weber, Modernity and the Project of International Organization." Cambridge Review of International Affairs 29 (4) (2016), 1502-1519. DOI 10.1080/o955 7571.2015.1020481.

Stone, Diane, and Kim Moloney, eds. The Oxford Handbook of Global Policy and Transnational Administration (Oxford: Oxford University Press, 2019).

Thomas, Huw, and Peter Turnbull. "From Horizontal to Vertical Labour Governance: 
The International Labour Organization (ILO) and Decent Work in Global Supply Chains." Human Relations 71 (4) (2018), 536-559. D OI 10.1177/oo18726717719994.

Trondal, Jarle. "A Research Agenda on International Public Administration." In The Rise of Common Political Order: Institutions, Public Administration and Transnational Space, ed. Jarle Trondal (Cheltenham: Edward Elgar, 2017), 35-48.

Tullock, Gordon. The Politics of Bureaucracy (Washington, DC: Public Affairs Press, 1965).

Urpelainen, Johannes. "Unilateral Influence on International Bureaucrats: An International Delegation Problem." Journal of Conflict Resolution 56 (4) (2012), 704-735. DOI 10.1177/oo22002711431423.

Vaubel, Roland. "Bureaucracy at the IMF and the World Bank: A Comparison of the Evidence." The World Economy 19 (2) (1996), 195-21o. DOI 10.1111/j.1467-9701.1996.tboo6 72.X.

Volgy, Thomas, Elizabeth Fausett, Keith Grant, and Stuart Rodgers. "Identifying Formal Intergovernmental Organizations." Journal of Peace Research 45 (6) (2008), 837-850.

Weber, Max. Economy and Society (Berkeley: University of California Press, 1978).

Weiss, Thomas G. International Bureaucracy: An Analysis of the Operation of Functional and Global International Secretariats (Lexington, MA: Lexington Books, 1975).

Wilson, Woodrow. "The Study of Administration." Political Science Quarterly 56 (4) (1941), 481-5o6.

Young, Oran R. "Political Leadership and Regime Formation: On the Development of Institutions in International Society." International Organization 45 (3) (1991), 281309. DOI 10.1017/Soo20818300033117. 